\title{
THE INFLUENCE OF STRESS ON THE HEALTH OF WORKERS IN MANUFACTURING INDUSTRY
}

\author{
Abdul Wahab Aidoo \\ International University of Sarajevo
}

\begin{abstract}
The frequent occurrence of stress and job-related-stress in recent times on workers at workplaces has become a trend of worry to: employers, management, employees, organizations, and society as a whole. Stress has a tremendous effect on job satisfaction, production, and workers' motivation. In this regard, the study methodology of this literature review focused on secondary sources of data. In-depth secondary sources of data was gathered to review trends of both past and current literatures and to elicit conclusion and recommendations for future studies. The sources of secondary data include; books, publications on internet, peer-reviewed journal articles, and etc. Furthermore, this research work shows that the presence of this phenomenon among workers has enormous influence on their job efficiency and effectiveness in the workplace. This study concludes that the frequent incident of intense stress on individuals conveys a sequence of disturbing and negative physiological and health consequences. Underlying effect is a reduction in the job performance due to illness, injury, absenteeism, quality control cost, turnover cost, and violence.
\end{abstract}

Keywords: Stress, Job Performance, Stress Consequence, Physiological and Health Problems.

\section{INTRODUCTION}

The frequent occurrence of stress and job-related-stress in recent times on workers at workplaces has become a trend of worry to: employers, management, employees, organizations, and society as a whole. Stress has a tremendous effect on job satisfaction, production, and workers' motivation. This prevailing phenomena at the workplace has made in inevitable for academicians, scholars, and researchers to investigate into its causes and probable consequences in order to offer significant recommendations as to how it can be managed, if not eradicated, to a sufficient minimum (Mettlin \& Woelfel, 1974). Researchers are of much concerned about the behavior of employers and managers in relation to the stress that workers undergo in their execution of their job (Pettergrew, Thomas, Ford, 
\& Raney, 1981).

The prevalent reportage of stress and its related problems at workplaces pose a scaring image for managers, supervisors, organizations and society as a whole. It is essential to handle the concept of job-stress not in a narrow perspective. However, it should be looked at in a broader environment, to encompass the cause and effect job related stress on the personality, the environment, and the working-family communication (Dar, Akmal, Naseem, \& Khan, 2011). According to Selye (1936) stress is involve in all the life of science. He explained that "stress is not necessary something bad - it all depends on how you take it. The stress of exhilarating, creative successful work is beneficial, while that of failure, humiliation or infection is detrimental". That is, stress is where an individual exert tremendous effort to resist factors such as: pressure, force, and strain from changing his current state or condition.

Workers job performance at the workplace can be explained as the judicious utilization of scarce resources (available to the worker) to successfully execute a task within a stipulated period of time. There is a relationship between job-stress and job-performance, and they are: 1.) stress causes production to fall, which means negative linear relationship, 2.) positive linear relationship, where stress causes production to rise, and 3.) U-shaped relationship, where job stress causes production to rise initially, attain its peak, then begins to fall (Dar, et. al., 2011).

This study concludes that the frequent incident of intense stress on individuals conveys a sequence of disturbing and negative physiological and health consequences. Underlying effect is a reduction in the job performance due to illness, injury, absenteeism, quality control cost, turnover cost, and violence. Evidence of these negative aftermaths is very alarming if management fails to recognize and institute necessary measures and policies to prevent the factors that create this canker.

\section{LITERATURE REVIEW}

One can assume that no individual at the workplace is exonerated Inquiry from stress, this is due the varying factors that trigger its occurrence. 2016/2 Every worker feels some form of strain and depressed in the discharge of his/ her duties. Stress and its related consequences have been in organizations and society for decades. A worker perceives stress when the job on him/ her is over burden (Hunter \& Thatcher, 2007). If the causative factor of this strain is very enormous, it will results in a severe consequence such as: psychological, physiological, physical, and mental disorder to the individual under stress (Health \& Safety, 2001).

Job stress can be defined as a unique organizational task that has the tendency to expose the worker to workplace hazards. This is usually 
evidence when the cordial relation between the worker and the working surrounding is distorted. The unique task has been conceptualize into psychiatric categories, and they include (Ilfeld, 1976):

State of depression. That is to feel lonely, dejected, and less energetic.

State of rage. Feeling angry, regular loss of temper, chastising others, feeling irritated, acting violence, and making argument over less significant matters.

State of anxiety. Exhibiting fear over trivial issues, regular upset, frequent stomach sour, and feeling dizzy.

Psychological disturbance. Having troubles in recollecting things, lack of concentration, and the mind becoming blank.

It has been recognized that the job stress pose a severe damage to the health of the individual stressor (Mimura \& Griffiths, 2003). The concept of job stress has become a bane for employers and managers due to its related dire effects on workers.

A high level of stress has the propensity to cause low production, job dissatisfaction, frequent truancy, and health challenges such as: drug abuse, alcoholism, hypertension, and cardiovascular related problems (Michie \& Williams, 2003). An exposure to stress over a long period of time can render problems in the area of: behaviour, physical health, and psychological to the individual (Kazi \& Haslam, 2013).

\section{METHODOLOGY}

A detailed literature review of secondary sources of data was performed to assess trends, draw conclusions. The data (from books, journal articles, and etc.) was analyzed to elicit conclusion and offer recommendations for future studies. Review of secondary sources of data was performed, thus, qualitative method of study was employed. Keywords were used as a form of a bait to look for secondary data from journals. The keywords include: stress, job performance, stress consequence, physiological and health problems. The study allocated 35 peer-review articles journal articles to use for the research. From these, 28 were posed importance to the review understudy, which represent $80 \%$. However, the rest of the 7 articles representing $20 \%$ were excluded due to the reason that they have no immense relevance to the study under review. A total of 4 academic books and 2 theses were used as a source of data significant to the study.

The data collected were analysed through the descriptive method of data analysis and interpreted to achieve the purpose of the study. 


\section{DISCUSSIONS}

\section{a.Stress Defined}

According to the works of Selye (1976) stress on human is explained as "the nonspecific response of the body to any demand". There are numerous factors that causes the human body and physiology to react in an unspecific manner. Under this study the factors that causes stress at the workplace has been categorized into four, namely:

- Environment

- Job-demand

- Structure of organization

- Family-work conflict

\section{i. Environmental Factor}

The physical surroundings at the workplace cannot be overlooked as a variable that instigate stress on the workers (Vagg \& Spielberger, 1998). Variables in the workplace such as: extreme level of noise, concentration of workers, and excessive temperature have high tendency of causing stress to workers. Haphazard placement of electronic cables and wires at the workplace surroundings can contribute to workers stress. Researchers have identified that spacious workplace environment where the distance from among workers are far apart reduces inter-personal communication, resulting in stress among the workers (Berry, 1998; William \& Cooper, 1988; Szilagyi \& Holland, 1980).

\section{ii. Job-demand Factor}

Firms practice division of labor, where each worker or group of workers are given a specific task to execute, to achieve the set goals and mission. In situations where the tasks that are demanded from labor are in contradictory and ambiguous with each other, it can cause frustration and hence, stress among the workers (Beehr, Jex, Stacy, \& Murray, 2000; Smither, 1998). Role and task which have characteristics feaancy, non-feedback behavior, and psychological strain among workers (Decker \& Borgen, 1993; Huensberg, Vedhara, Nott, \& Bradbeer 1998; Breaugh, 1980).

\section{iii. Structure of Organization}

It is significant to point out that researchers have recognized a seeming relationship between the position held by workers and the occurrence of labor stress at the workplace environment. The extensive research study on stress, undertaken by Ivancevich, Matteson, Freed- 
man, and Phillips (1990) were concentrated on five characteristics of stress within the levels of management in an organizational structure, and they include:

- Excessive quantitative job load.

- Excessive qualitative job load.

- Less progress in career.

- Relations with supervisor.

- Task contradiction.

- Time constraint (Parasuraman \& Aluto, 1981).

\section{Table 1: Review of Empirical Studies on the Concept of Stress}

\begin{tabular}{|c|c|c|}
\hline Study & Research Design & Theory \\
\hline Dar, Akmal, Naseem, \& Khan (2011) & $\begin{array}{l}143 \text { managers, professors, } \\
\text { lecturers, supervisors, and } \\
\text { workers, structured question- } \\
\text { naire, cross-sectional. }\end{array}$ & $\begin{array}{l}\text { nature and position } \\
\text { of job }\end{array}$ \\
\hline Fink \& Schaubroeck, (1998) & $\begin{array}{l}214 \text { employees, structured } \\
\text { questionnaire, cross-sectional }\end{array}$ & $\begin{array}{l}\text { support and control } \\
\text { in relation to job per- } \\
\text { formance }\end{array}$ \\
\hline Kazi \& Haslam (2013) & $\begin{array}{l}\text { Phase } 1 \text { study, employee } \\
\text { survey; Phase } 2 \text { study, focus } \\
\text { groups, structured question- } \\
\text { naire; } 304 \text { survey, self-report } \\
\text { questionnaire, cross-sectional }\end{array}$ & $\begin{array}{l}\text { health and job atti- } \\
\text { tudes }\end{array}$ \\
\hline Pettergrew, Thomas, Ford, \& Raney (1981) & $\begin{array}{l}518 \text { employees at medical } \\
\text { centre, structured question- } \\
\text { naire, cross-sectional }\end{array}$ & $\begin{array}{l}\text { communication is } \\
\text { situational influenced }\end{array}$ \\
\hline Neff \& Karney (2007) & $\begin{array}{l}169 \text { couples, telephone inter- } \\
\text { view }\end{array}$ & $\begin{array}{l}\text { stress spill over, in- } \\
\text { trapersonal effect }\end{array}$ \\
\hline Beehr, Jex, Stacy, \& Murray (2000) & $\begin{array}{l}198 \text { university students, } \\
\text { structured questionnaire, } \\
\text { cross-sectional }\end{array}$ & $\begin{array}{l}\text { occupation specific, } \\
\text { occupational stressors }\end{array}$ \\
\hline Netemeyer, Maxham, \& Pullig (2005) & $\begin{array}{l}452 \text { employees in organiza- } \\
\text { tions, electronic interview, }\end{array}$ & $\begin{array}{l}\text { job stress and per- } \\
\text { formance }\end{array}$ \\
\hline Dubinsky, Michaels, Kotabe, Lim \& Moon (1992) & $\begin{array}{l}594 \text { sales personnel, elec- } \\
\text { tronic interview }\end{array}$ & $\begin{array}{l}\text { robust and consist- } \\
\text { ence role stress model, } \\
\text { conflict and ambiguity } \\
\text { effect }\end{array}$ \\
\hline Kelloway, Barling, \& Shah (1993) & $\begin{array}{l}229 \text { industrial employees, } \\
\text { structured questionnaire, } \\
\text { cross-sectional }\end{array}$ & $\begin{array}{l}\text { negative and positive } \\
\text { mood correlates with } \\
\text { job satisfaction }\end{array}$ \\
\hline Nygaard \& Dahlstrom (2002) & $\begin{array}{l}218 \text { retail managers, elec- } \\
\text { tronic interview }\end{array}$ & $\begin{array}{l}\text { conflict impacts on } \\
\text { ambiguity to sales, } \\
\text { conflict directly relates } \\
\text { to specific investment }\end{array}$ \\
\hline
\end{tabular}


The category of workers at the lower level departments (or functions) has technical challenges and frustrations as their main cause of stress at the workplace (Yost, 2002).

\section{iv. Family-Work Factor}

Issues like: misunderstanding, disagreement, or conflict among family members is a major cause for alarm for members of organizations. Family conflict disrupts the tranquillity of work, which causes tension and stress to the worker (Netemeyer, Maxham, \& Pullig, 2005). Work-life balance has been a bane for many workers especially those in high level management. According to the study by Bartolome and Evans (1979) from a total of 532 middle-aged managers $80 \%$ assign equal importance to job career and family, however, they spent ample time on their career. Over $50 \%$ of reported their discontent with the amount of time allocated for family and leisure life. Coincidentally, the dissatisfied sample of workers showed more high level of stress at workplace.

\section{b. Stress in the Manufacturing Industry}

A research study conducted in Canada, with a sample size of 3,500 workplaces showed that, $50 \%$ of firms are wary of workers exposed to extreme temperatures, stuffy atmosphere, injuries, and strain. While $33 \%$ are worried about excessive noise, poor spacing, lack of lighting, explosion, straining of eyes, hazardous chemicals, exposed machinery, and lack of preventive training (Mazerall, 2002).

Workers in the manufacturing industry are exposed to frequent and divert forms of stressor, and they include (Mazerall, 2002):

- Extreme noise.

- Less amount of lighting.

- Stuffy atmosphere.

- High temperatures.

- Mechanical (physical) menace.

\section{i. Extreme Noise}

Workers exposure to severe noise above their physiological threshold limit results in stress. Extreme noise can cause minor itching and complete loss of hearing (Lusk, 1997). For instance, a survey conducted by the human resources development Canada (HRDC) in 1998, revealed that 1,101 workers who have been exposed to extreme noise are battling with hearing loss. These noises are usually produced by machines, tools, and equipment that are used in the production process (Mazerall, 2002). 


\section{ii. Less Amount of Lighting}

Significant amount of lighting at the workplace environment is necessary for vision. Studies conducted reveal that there is a positive relation between adequate illuminations at the workplace environment and health (especially eye-sight) of workers. Deficient lighting at the environment results in straining of the eyes which may lead to irritations, tiredness, headache, and accidents (Scott, 1997).

\section{iii. Stuffy Atmosphere}

Production environments are exposed to air pollution which is as a result of smoke, gas, dust, vapour, filthy area, excessive crowding, and effervescent from chemicals (Kazi \& Haslam, 2013). These materials are harmful to the health of workers. These makes the workers susceptible to physiological and biochemical changes to conditions such as: sneezing, coughing, respiratory difficulty, and cardiovascular challenges (Mazerall, 2002). These physiological changes may put stress on the workers.

\section{iv. High Temperature}

Extreme environmental temperatures above threshold levels at the workplace become a burden for workers. Their physiological systems are not able to adapt to such changes. Extreme cold temperatures make one sluggish stress, while extreme hot temperatures make an individual to profusely dehydrate and become fatigue stress (Scott, 1997). Results from HRDC's survey in 1998 revealed that average of 54 incidents of time lost occurred at workplaces due to tiredness and heat cramps (Mazerall, 2002).

\section{c. Physiological Challenges of Stress}

According researchers, stress brings about physical health and physiological health challenges (Kazi \& Haslam, 2013; Allen, 1991). Physiological effects that generally occur from stress include (DeFrank \& Ivancevich, 1998; Allen, 1991):

- Rise in perspiration.

- Increased heartbeat and breathing rate.

- Rise in blood pressure.

- Nausea.

- Vibration of limbs.

- High decrease in breath.

Frequent and long period of exposure to stress is a bane to the individual. It can result in severe physiological and long term health dam- 
ages. For instance, between 1987 to 1994 in Netherland the percentage of labor who benefited from "disability pensions" as a result of "stress related" maladies increased from 21\% - 30\% (Hek \& Plomp, 1997). The common physiological and health damages associated with continuous conditions of stress include (DeFrank \& Ivancevich, 1998; Allen, 1991):

- Ulcers.

- Diabetes.

- Migraine.

- High blood pressure.

- Flu.

\section{Figure 1: Stress effect on Health}

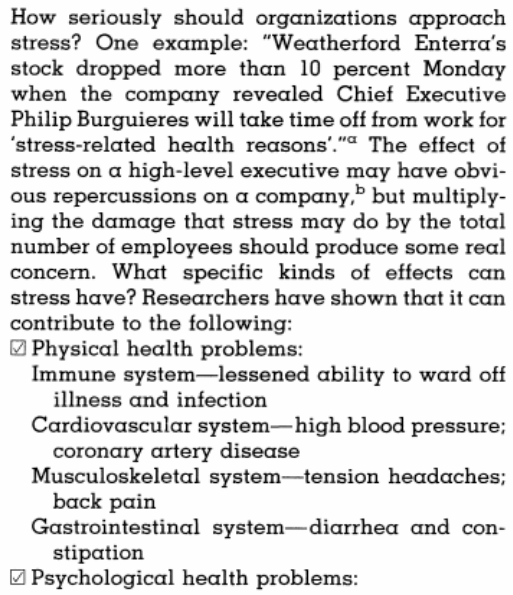

How seriously should organizations approach stress? One example: "Weatherford Enterra's stock dropped more than 10 percent Monday when the company revealed Chief Executive Philip Burguieres will take time off from work for 'stress-related health reasons'." $a$ The effect of stress on a high-level executive may have obvious repercussions on a company, ${ }^{b}$ but multiplying the damage that stress may do by the total number of employees should produce some real concern. What specific kinds of effects can stress have? Researchers have shown that it can contribute to the following:

$\square$ Physical health problems:

Immune system-lessened ability to ward off illness and infection

Cardiovascular system-high blood pressure; coronary artery disease

Musculoskeletal system-tension headaches; back pain

Gastrointestinal system-diarrhea and constipation

$\square$ Psychological health problems:

Depression; anxiety; anger/hostility; lower self-confidence

$\square$ Behavioral problems:

Decreased performance/productivity

Decreased job satisfaction; absenteeism/turn-

over; sabotage

Workplace injuries

These problems have a distinct monetary cost to business, often estimated at upwards of $\$ 200-\$ 300$ billion a year. ${ }^{c}$ But beyond those costs lies the concern that excess stress distracts employees and management alike from exhibiting the drive, the customer focus, and the innovativeness required for organizations in today's marketplace.

Source: DeFrank \& Ivancevich, 1998

It can be deduced from figure 1 that physical health, psychological Inquiry health and behavioural problems of workers are caused by stress. Phys2016/2 ical health systems of individuals such as: immune system, cardiovascular system, musculoskeletal system, and gastrointestinal systems are threatened because of continuous stress. Depression, rage, lack of selfesteem, and nervousness are some of the psychological problems associated with stress. Lastly, behavioural conditions such as truancy, job dissatisfaction, decrease in energy, disruption, and workplace damages (wound) are eminent. 


\section{CONCLUSION}

This comprehensive secondary (literature) review research acknowledged that numerous elements contribute to the stress and stress-related matters of workers in organizations. These elements, among many others, include: the environment, demand from job (task), structure of the organizations, and family-work life balance. Stress has in organizations have a negative impact on the workforce. The intensity of stress on workers correlates with the form and severity of factors that triggers it.

This study concludes that the frequent incident of intense stress on individuals conveys a sequence of disturbing and negative physiological and health consequences. Underlying effect is a reduction in the job performance due to illness, injury, absenteeism, quality control cost, turnover cost, and violence. Evidence of these negative aftermaths is very alarming if management fails to recognize and institute necessary measures and policies to prevent the factors that create this canker.

This study has tried to advance the concept of stress and stress-related issues harboring in workplace environments. This concept has a direct and adverse effect on the health and job performance of workers. Researchers and academicians may investigate more into the concept on stress, to find out the diverse ways and factors to adopt to manage (if not completely eradicate) it at workplace. Stress can be used positively in certain organizations to increase job performance. As stress increases gradually at the initial stage job performance will increase, it reaches a peak then begins to decline. Factors which will cause stress to increase job performance at workplaces should be recognized and supported. 


\section{REFERENCES}

Bartolome, F., \& Evans, P. (1979). Professional lives versus private lives: shifting patterns of managerial commitment. Organizational Dynamics, 8, 3-29.

Beehr, T. A., Jex, S. M., Stacy, B. A., \& Murray, M. A. (2000). Work stressors and coworker support as predictors of individual strain and job performance. Journal of Organizational Behavior, 21(4), 391-405.

Berry, L. M. (1998). Psychology at work (2 ${ }^{\text {nd }}$ ed.). New York: McGraw-Hill.

Breaugh, J. A. (1980). A comparative investigation of three measures of role ambiguity. Journal of Applied Psychology, 65, 584-589.

Dar, L., Akmal, A., Naseem, M. A., \& Khan, K. U. D. (2011). Impact of stress on employees job performance in business sector of Pakistan. Global Journal of Management and Business Research, 11(6), 1-4.

Decker, P. J., \& Borgen, F. H. (1993). Dimensions of work appraisal: stress, strain, coping, job satisfaction, and negative affectivity. Journal of Counselling Psychology, 84(4), 874-884.

DeFrank, R. S., \& Ivancevich, J. M. (1998). Stress on the job: an executive update. The Academy of Management Executive (1993-2005), 12(3), 55-66

Health \& Safety. (2001). Executive, tackling work-related stress: A guide for employees. INDG341. Sudbury: HSE Books.

Hek, H. V., \& Plomp, H. N. (1997). Occupational stress management programmes: a practical overview of published effect studies. Occupational Medicine, 47(3), 133-141.

Huensberg, M., Vedhara, K. Nott, K. H., \& Bradbeer, C. (1998). An exploration into occupational stress experienced by HIV health care professionals who work within genitourinary medicine settings. Journal of Occupational Health Psychology, 3(1), 83-89.

Hunter, L. W., \& Thatcher, S. M. B. (2007). Feeling the heat: effects of stress, commitment, and job experience on job performance. The Academy of Management Journal, 50(4), 953-968.

Ilfeld, F. W. Jr. (1976). Further validation of a psychiatric symptom index in a normal population. Psychological Reports, 39, 1215-1228.

Ivancevich, J. M., Matteson, M. T., Freedman, S. M., \& Phillips, J. S. (1990). Worksite stress management interventions. American Psychologist, 45(2), 252-261.

Kazi, A., \& Haslam, C. O. (2013). Stress Management Standards: a warning indicator for employee health. Occupational Medicine, 63, 335-340.

Mazerall, L. (2002). Stress management within a manufacturing environment. (Masters Theses). Retrieved from ProQuest Dissertations and Theses database. (UMI No. 800-521-0600).

Mettlin, C., \& Woelfel, J. (1974). Interpersonal influence and symptoms of stress. Journal of Health and Social Behavior, 15, 311-319.

Michie, S., \& Williams, S. (2003). Reducing psychological ill health and associated sickness absence: A systematic literature review. Occupational and Environmental Medicine, 60, 3-9. 
Mimura, C., \& Griffiths. (2003). The effectiveness of current approaches to workplace stress management in the nursing profession: An evidence based literature review. Occupational and Environmental Medicine, 60, 3-9.

Netemeyer, R. G., Maxham, J. G., \& Pullig, C. (2005). Conflict in the work-family interface: links to job stress, customer service employee performance, and customer purchase intent. Journal of Marketing, 69(2), 130-143.

Parasuraman, S., \& Aluto, I. A. (1981). An examination of the organizational antecedents of stressors at work. Academy of Management Journal, 24, 48-67.

Pettergrew, L. S., Thomas, R. C., Ford, J., \& Raney, D. C. (1981). The effects of job-related stress on medical centre employee communicator style. Journal of Occupational Behaviour, 2(4), 235-253.

Scott, R. (1997). Basic concepts of industrial hygiene. New York: Lewis.

Selye, H. (1936). A syndrome produced by diverse noxious agents. 138, 32. In Dar, L., Akmal, A., Naseem, M. A., \& Khan, K. U. D. (2011). Impact of stress on employees' job performance in business sector of Pakistan. Global Journal of Management and Business Research, 11(6), 1-4.

Smither, R. D. (1998). The psychology of work and human performance ( $3^{\text {rd }} \mathrm{ed}$.). New York: Addison Wesley Longman.

Szilagyi, J. K., \& Holland, W. E. (1980). Change in social density: relationships with functional interaction and perceptions of job characteristics, role stress, and work satisfaction. Journal of Applied Psychology, 65, 28-33.

Vagg, P. R., \& Spielberger, C. D. (1998). Occupational stress: measuring job pressure and organizational support in the workplace. Journal of Occupational Health Psychology, 3(4), 294-305.

William, S., \& Cooper, C. L. (1998). Measuring occupational stress: development of the pressure management indicator. Journal of Occupational Health Psychology, 3(4), 306-321.

Yost, J. S. (2002). Workplace stress related to organizational change in telecommunications management employees. (Doctoral dissertation). Retrieved from ProQuest Dissertations and Theses database. (UMI No. 3036970). 
